\title{
Assessing Higher Education in the COVID-19 Era
}

\section{Brock Brock Education}

A journal of educational research and practice

2020 Vol. 29 (2) 37-41

https://journals.library.brocku.ca/brocked

\section{Rahul Kumar* \\ Brock University}

\begin{abstract}
COVID-19 has changed how universities operate. The changes are in all spheres and caused by demands of social distancing rules predominantly mediated by various digital technologies. Applying Bauman's (1993) ethics of technology on newly initiated assessment practices, this article raises ethical concerns of relying on solutions solely manufactured by technology companies without professors' and students' input, various considerations of privacy, and overall ethical concerns that the use of any new technology raises. The article concludes by beseeching all stakeholders to collaborate to construct the tools for tomorrow that meet pedagogical needs without compromising Bauman's ethical concerns.

Keywords: higher education, ethics, technology, COVID-19 issues

*rkumar@brocku.ca
\end{abstract}


Status quo in higher education is, in part, preserved by operational inertia. The jolt of a 0.125 micron virus named COVID-19 has disrupted this status quo. Itself fragile, itself vulnerable to being washed away by everyday common soap, COVID-19 has altered many deep-seated conventions and norms within higher education that have had to reform. The question is which of the adopted changes will persist? Which will outlast COVID-19? Put another way, which practices will lose their luster and favour with time? What will constitute the new normal? Using assessment of learning as one small exemplar, this essay makes a case for a collective vision to ameliorate practices and for reflection on the underlying beliefs of adopting various forms of technology.

In March 2020, the regular teaching, research, and administrative operations in universities ceased abruptly. Yet, thousands of students needed to finish their terms and year, which was only a few weeks short of their respective disciplinary requirements. First, Information and Communication Technologies (ICT) were employed to finish the academic term when normal operations ended on most campuses. Upon reaching the finish line of the term, complacency and innocence have had to make way for deliberate and intentional efforts, which were subsequently adopted in the ensuing Spring term and are here to stay for at least the 2020-2021 academic year. Proponents and prophets of online teaching and ICT consider this pandemic to be the catalyst to bring about the changes which they had been lobbying for a long time. Some (the administrative cadre, chief among them) posit that these changes are here to stay permanently. This has led many to seriously contemplate issues such as: How will student learning change? How will faculty practices change? How will administrative functions change? The question that is of paramount interest here is which of the changes ushered in by COVID19 are here to stay and at what cost? What other new challenges will they introduce and what proactive approaches can be taken to improve teaching and learning? Concomitant with these sets of questions and assumptions is the idea that the introduction of new technologies or new forms of technologies brings with it a new set of issues-some anticipated and therefore perhaps accounted for, while others still unforeseen.

The use of ICT in delivering content, engaging students through various online tools, and then assessing their acquisition and retention of knowledge in conventional ways poses some interesting challenges. The underlying assumption here is that more technology is needed to resolve or at least lessen problems the technology has introduced in the first place. For assessment processes, technology has been advocated to monitor and proctor students writing their exams. Some of the ways in which intrusive forms of technologies have migrated (or are attempting to migrate or even be welcomed) to students' homes for invigilation include: cameras coupled with artificial intelligence technology in the software to monitor exam takers and flag those who might be looking away from the monitor screens while taking tests; audio 
monitoring for talking that might occur in the room where students write exams (including use of other languages); and blocking other websites on the computers. This recognition is at least a trigger to refine new methods and technologies used in higher education practices or even perhaps a summons to require large-scale reforms in conventional modalities of assessment. Refinement, while quick and appealing, is liable to miss the mark, especially if the majority of subsequent teaching and learning is going to occur online, mediated by ICT. This is further complicated and necessary if, as predicted, some disciplines will move to online modalities even post COVID-19.

Unless well-meaning and sincere reforms within higher education are undertaken, practices adopted within certain disciplines (including education) will be determined by complete outsiders. By outsiders, I mean those who design, code, and sell the tools. Zygmunt Bauman (1993) warns that complacency of those in the field will empower technology and make it a closed system. If this were to happen, technology and its masters (technicians) alone will dictate the terms of what prevails:

What is closed here seems to be a system of self-corroborating beliefs: technology setting the vocabulary of the world's narrative in a way that allows nothing but technological action and that expresses any worry and trouble as a demand for a "technological fix." (Bauman, 1993, p. 187)

That is, a reluctance in reimagining new forms of assessment has already sprung up businesses offering new technologies, and their use has increased more than tenfold since the pandemic was announced (Doffman, 2020). There are many commercial options available (e.g., ExamMonitor from ExamSoft.com; Guage by test.com; Proctorio by proctorio.com) with many features that claim to preserve academic integrity. Questions emerge that are worth pondering: Are intrusive technologies the price of university education? Is this the ecoculture that the post COVID-19 world will create for higher education? What limits would be imposed? In Doffman's (2020) reporting, Proctorio's CEO admits such products are a necessary evil because of the environment that has emerged.

Bauman (1993) cautions us that the technological closed environment subsumes the rest of the world around it-students, teachers, curricula. Bauman explains this environment as a source of food, raw matter for technological treatment, or the dumping ground for the waste of that treatment; and it defines its own misadventures or misdeeds as effects of its own insufficiency, and the resulting "problems" as demands for more of itself: the more "problems" technology spawns, the more technology is needed. (p. 186)

A worrisome prognosis for sure, but I do not give in to hopelessness. Instead, I hope to elicit collective, collaborative, and inclusive approaches from faculty, students, administrators, and even members from outside the academy to contribute to the solutions rather than delegating technicians alone to solve the problems. Let the technological initiatives and efforts be aimed 
towards the things they alone can do. Let non-creepy solutions to the problems faced today within higher education emerge from the collective wisdom of those who Barnard (1938/1968) identifies as being in the zone of sensitivity and committed to this enterprise.

The solutions that are to emerge in the higher education space have to balance propositions from the ardent supporters and the vehement critics of new, burgeoning forms of teaching, learning, and assessing in the COVID-19 shaped world. While it might be expedient to dismiss some, it would be reckless to do so because "meaning is always round the corner, always inwaiting and not-yet, the 'what is' has no authority over 'what ought to be'" (Bauman, 1993, p. 194). In other words, practices cannot be defended based on a we-have-always-done-it-thisway approach. More imaginative practices-in teaching, learning, and forms of assessment of learning - will have to be devised and implemented, with or without mediation of technology.

If we in the academy do not take this responsibility seriously, the erosion of the public opinion of higher education, which in certain pockets had already started to occur (Lederman, 2019; Schleifer \& Silliman, 2016) will speed up. In the U.S., calls for reimagining the purpose of higher education are already gaining momentum (Merisotis \& Hauser, 2020). It is hard to imagine that similar sentiments would be too distant here.

As Bauman (1993) asserts, "It is a general feature of social change that while it puts or attenuates the wrongs of yesterday, it also ushers in new wrongs bound to become a target of curative efforts tomorrow" (p. 223). The realization and the possibilities of ICT that have occurred are not reason enough for us to bestow all pedagogical responsibilities to technology. Rather, we are responsible to engage a principled and ethical stance, lest Bauman's concerns be our realities to confront tomorrow. Stay safe by vigilance!

\section{References}

Barnard, C. I. (1968). The functions of the executive. Harvard University Press. (Original work published 1938)

Bauman, Z. (1993). Postmodern ethics. Blackwell.

Doffman, Z. (2020, April 24). Exam monitoring webcam tech meets student outrage. Forbes. https:/ / www.forbes.com/sites/zakdoffman/2020/04/24/no-lockdown-exams-sorrykids-this-creepy-webcam-tech-lets-you-sit-them-at-home/

Lederman, D. (2019, June 17). The public support for (and doubts about) higher ed. Inside Higher Ed. https://www.insidehighered.com/news /2019/06/17/survey-shows-publicssupport-and-qualms-about-higher-education 
Merisotis, J., \& Hauser, C. B. (2020, May 18). A time to reflect on what college should be. Inside Higher Ed. https://www.insidehighered.com/views/2020/05/18/colleges-must-deliverwhat-matters-most-students-employers-and-society-opinion

Schleifer, D., \& Silliman, R. (2016, October). What's the payoff? Americans consider problems and promises of higher education. Public Agenda. https://www.publicagenda.org/wpcontent/uploads /2019/11/WhatsThePayoff_PublicAgenda_2016.pdf 